\title{
Assessment of the Relationship between Serum Vitamin D and Osteocalcin Levels with Metabolic Syndrome in Non-Osteoporotic Postmenopausal Women
}

\author{
Beurteilung der Beziehung zwischen Vitamin-D- und \\ Osteocalcin-Blutwerten und metabolischem Syndrom \\ bei Frauen ohne Osteoporose nach der Menopause
}

\section{(C) (1) (오 $\ominus$}

Authors

Gurhan Guney ${ }^{1}$, Bilge Sener-Simsek², Aytekin Tokmak², Aykan Yucel², Umran Buyukkagnici³ ${ }^{3}$ Nafiye Yilmaz², Yaprak Engin-Ustun ${ }^{2}$, A. Seval Ozgu-Erdinc ${ }^{2}$

\section{Affiliations}

1 Sakarya University Education and Research Hospital, Department of Obstetrics and Gynecology, Sakarya, Turkey

2 University of Health Sciences, Zekai Tahir Burak Women's Health Research and Education Hospital, Department of Obstetrics and Gynecology, Ankara, Turkey

3 University of Health Sciences, Zekai Tahir Burak Women's Health Research and Education Hospital, Department of Biochemistry, Ankara, Turkey

Key words

menopause, metabolic syndrome, osteocalcin, vitamin D, osteoporosis, insulin resistance

\section{Schlüsselwörter}

Menopause, metabolisches Syndrom, Osteocalcin, Vitamin D, Osteoporose, Insulinresistenz

$\begin{array}{ll}\text { received } & 22.12 .2017 \\ \text { revised } & 27.7 .2018 \\ \text { accepted } & 19.10 .2018\end{array}$

Bibliography

DOI https://doi.org/10.1055/a-0767-6572

Published online 22.1. 2019 | Geburtsh Frauenheilk 2019; 79:

293-299 @ Georg Thieme Verlag KG Stuttgart · New York I ISSN 0016-5751

Correspondence

Gurhan Guney

Sakarya University Education and Research Hospital

Adnan Menderes Boulevard, Saglik Street, No: 195,

Sakarya 54100, Turkey

gurhanguney@yahoo.com

\section{ABSTRACT}

Introduction The aim of this study was to compare serum vitamin D and osteocalcin levels in non-osteoporotic postmenopausal women with and without metabolic syndrome and to analyze the relationship between serum vitamin D and osteocalcin levels and the relationships between these two factors and other clinical/biochemical parameters.

Material and Method This cross-sectional study was carried out in 191 postmenopausal non-osteoporotic (T-score > - 2.5) women. Patients were divided into two groups according to the presence or absence of metabolic syndrome. Blood samples were obtained and evaluated for 25-hydroxyvitamin D, osteocalcin, insulin resistance (using a homeostatic model assessment of insulin resistance), glycosylated hemoglobin $\left(\mathrm{HbA}_{1 \mathrm{c}}\right)$, calcium, phosphorus, deoxypyridinoline, thyroidstimulating hormone, lipid profile, fasting insulin, fasting glucose and $\mathrm{HbA}_{1 \mathrm{c}}$ levels. Demographic and laboratory parameters were recorded for each woman.

Results Vitamin D was found to be lower in women with metabolic syndrome compared to controls $(16.1 \pm 11.2$ vs. $20.4 \pm 13.1 \mathrm{mg} / \mathrm{dL} ; \mathrm{p}=0.013)$. Similarly, osteocalcin was found to be significantly lower in the metabolic syndrome group compared to the control group $(4.2 \pm 2.1$ vs. $5.5 \pm 3.0 ; p<0.001)$. A significant positive correlation was observed between vitamin $D$ and osteocalcin levels $(r=0.198 ; p=0.008)$. There was an inverse correlation between vitamin $D$ and some of the lipid parameters. However, osteocalcin levels were negatively correlated with $\mathrm{C}$-reactive protein, insulin resistance, and $\mathrm{HbA}_{1 \mathrm{c}}$ in both groups ( $p=0.003, p=0.001$ and $p=0.048$, respectively).

Conclusion Vitamin D deficiency is common in postmenopausal women, even in women who are non-osteoporotic. Serum levels of vitamin D are significantly decreased in cases with metabolic syndrome. Vitamin D may directly improve serum lipid profiles and may indirectly decrease insulin resistance and subclinical systemic inflammation through the impact on the metabolic functions of osteocalcin. 


\section{ZUSAMMENFASSUNG}

Einleitung Ziel dieser Studie war es, die Vitamin-D- und Osteocalcin-Blutwerte bei Frauen ohne Osteoporose nach der Menopause mit und ohne metabolischem Syndrom zu vergleichen und die Beziehungen zwischen Vitamin D und Osteocalcin sowie zwischen diesen beiden Faktoren und anderen klinischen und biochemischen Parametern zu analysieren.

Material und Methode Diese Querschnittsstudie wurde bei 191 Frauen ohne Osteoporose (T-Score $>-2,5$ ) nach der Menopause durchgeführt. Die Patientinnen wurden in 2 Gruppen eingeteilt, je nach Vorhandensein oder Abwesenheit eines metabolischen Syndroms. Allen Frauen wurden Blutproben entnommen und auf 25-Hydroxy-Vitamin D, Osteocalcin, Insulinresistenz (basierend auf ein homöostatisches Modell zur Beurteilung der Insulinresistenz), glykosyliertes Hämoglobin $\left(\mathrm{HbA}_{1 \mathrm{c}}\right)$, Kalzium, Phosphor, Desoxypyridinolin, Thyreotropin, Lipidprofil, Nüchternblutzucker, Nüchternglukosewerte sowie die $\mathrm{HbA}_{1 \mathrm{c}}$-Werte untersucht. Die gewonnenen demografischen und Laborwerte wurden für jede der Frauen aufgezeichnet.
Ergebnisse Frauen mit einem metabolischen Syndrom wiesen einen niedrigeren Vitamin D-Spiegel auf im Vergleich zur Kontrollgruppe (16,1 $\pm 11,2$ vs. $20,4 \pm 13,1 \mathrm{mg} / \mathrm{dl}$; $p=0,013$ ). Auch die Osteocalcin-Werte waren signifikant niedriger in der Gruppe mit metabolischem Syndrom verglichen mit der Kontrollgruppe $(4,2 \pm 2,1$ vs. $5,5 \pm 3,0 ; p<0,001)$. Es gab eine signifikante positive Korrelation zwischen Vitamin-D- und Osteocalcin-Werten $(r=0,198 ; p=0,008)$. Vitamin $D$ und einige der Lipidparameter waren invers korreliert. Allerdings gab es eine negative Korrelation in beiden Gruppen zwischen dem Osteocalcin-Spiegel und C-reaktivem Protein, Insulinresistenz und $\mathrm{HbA}_{1 \mathrm{c}}(\mathrm{p}=0,003, \mathrm{p}=0,001$ bzw. $\mathrm{p}=0,048)$.

Schlussfolgerung Vitamin-D-Mangel kommt häufig vor bei Frauen nach der Menopause, selbst bei Frauen, die keine Osteoporose haben. In Fällen mit metabolischem Syndrom waren die Vitamin-D-Werte im Blut deutlich reduziert. Vitamin D könnte zu einer direkten Verbesserung der Lipidprofilwerte und indirekt zu einem Rückgang der Insulinresistenz und der subklinischen systemischen Entzündung führen, durch dessen Auswirkung auf die metabolische Funktion von Osteocalcin.

\section{Introduction}

Vitamin $\mathrm{D}$ is synthesized in skin following exposure to UV-B radiation from sunlight. It is a sterol group hormone rather than a vitamin and the liver and kidneys play an active role in the subsequent synthesis of vitamin D [1]. It is called a hormone because it is synthesized in the body and connects to receptors to perform its functions [2].

One of the most important functions of Vitamin $\mathrm{D}$ is the promotion of bone mineralization. Other important functions include inhibition of cellular proliferation, induction of terminal differentiation, inhibition of angiogenesis, induction of insulin production and inhibition of renin production [3].

Vitamin D deficiency is the most common nutritional deficiency worldwide. Decreased oral intake, poor nutrition, limited sun exposure, malabsorptive conditions, liver and kidney failure and obesity may explain this high prevalence. The fact that vitamin D levels can be low in persons with normal bone mineral density indicates that there may be some compensatory mechanisms which prevent this deficiency from affecting bone density [4].

The presence of a cluster of several cardiovascular risk factors such as insulin resistance, obesity, atherogenic dyslipidemia and hypertension is referred to as metabolic syndrome. Metabolic syndrome is characterized as one of the major health problems of postmenopausal women and is a major cause of cardiovascular morbidity and mortality in this group of women [5].

Studies conducted in different parts of the world have reported that the prevalence of metabolic syndrome in postmenopausal women may be as high as $41.5 \%[6,7]$.

Osteocalcin is a circulating biomarker that can be used to determine the quality of bone tissue, and its production requires vitamin $D[8,9]$. It is a non-collagenous protein hormone synthesized by vitamin K-dependent pathways during bone turnover.
More and more evidence is accumulating that osteocalcin, which is secreted from osteoblasts, also plays a role in glucose and fat regulation in addition to its role in bone mineralization and calcium homeostasis [10,11].

Previous studies have shown a significant association between metabolic syndrome and vitamin D levels, but the assocation with osteocalcin levels in postmenopausal patients with normal bone mineral densities has never been previously investigated. There is a suggestion is that the relationship between osteocalcin and vitamin $D$ levels may be a determinant of metabolic syndrome.

In this study we aimed to investigate the relationship between vitamin D and osteocalcin levels in non-osteoporotic postmenopausal women who were diagnosed as having metabolic syndrome.

\section{Material and Methods}

\section{Study design}

This cross-sectional study was performed in Zekai Tahir Burak Women's Health Education and Research Hospital, Ankara, a tertiary center in the capital city of Turkey. A total of 191 postmenopausal women admitted to our outpatient menopause clinics for routine clinical examination and investigation of osteoporosis were included in the study after we obtained their informed consent. The study was carried out between September 2013 and November 2013, which coincides with autumn in our country. Ankara has a continental climate (average temperature: $20-25^{\circ} \mathrm{C}$, altitude: $891 \mathrm{~m}$, latitude: 40-40 N, longitude: 32-340 E). Spring and autumn are the seasons with the most rainfall. During the study it rained on 3-4 days of every month. This study was approved by the local ethics committee and by the hospital's current 
institutional review board, and all study protocols were carried out in accordance with the Declaration of Helsinki [12].

\section{Study participants}

Women with chronic diseases such as autoimmune disease, neoplasia, cancer and AIDS, skin diseases and women who had been given vitamin D supplements or analogues (including alphacalcidol, calciferol and cholecalciferol) over the past 12 months were excluded from the study. None of the individuals involved in the study received any medical treatment for bone disease. A DEXA scan was carried out in all of the women included in the study to determine femur-neck, total femur and total L1-L4 bone density. The T-score was more than -2.5 for all of the investigated patients.

Metabolic syndrome was defined according to the 2006 consensus definition of the International Diabetes Federation and includes abdominal obesity (waist circumference [WC] $\geq 80 \mathrm{~cm}$; if the $\mathrm{BMI}$ is $>30 \mathrm{~kg} / \mathrm{m}^{2}$, it is assumed that central obesity is present and the waist circumference does not need to be measured) plus two of the following criteria: hypertriglyceridemia (triglycerides [TG] $\geq 150 \mathrm{mg} / \mathrm{dL}$ ), high-density lipoprotein cholesterol (HDL-C) $<50 \mathrm{mg} / \mathrm{dL}$, hypertension (blood pressure $\geq 130 / 85 \mathrm{mmHg}$ ), and hyperglycemia (fasting plasma glucose $\geq 100 \mathrm{mg} / \mathrm{dL}$ ) [13]. WC was measured at the umbilicus, using a cloth tape. Blood pressure was measured from the right arm after the patient had rested for ten minutes, using a mercury sphygmomanometer and with the patient in a sitting position. Patients using antihypertensive drugs were classed as hypertensive, and patients previously diagnosed with diabetes mellitus (DM) and receiving treatment or with fasting plasma glucose $>126 \mathrm{mg} / \mathrm{dl}$ were classed as having DM. Insulin resistance was calculated using the following formula: homeostatic model assessment of insulin resistance $(\mathrm{HOMA}-\mathrm{IR})=$ plasma fasting insulin $(\mathrm{mlU} / \mathrm{L}) \times$ plasma fasting glucose $(\mathrm{mmol} / \mathrm{L}) / 405$.

Following a fast of at least eight hours, approximately $5 \mathrm{cc}$ of venous blood were taken from the antecubital vein and filled into gel tubes. Blood samples were sent to the laboratory in a lighttight box to avoid exposure to light and centrifuged at $4000 \mathrm{\mu g}$ for 10 minutes. The serum was separated and analyzed immediately. Serum levels of hormones including FSH, E2 and insulin were measured using the UniCel Dxl 800 Immunoassay System (Beckman Coulter, Fullerton, CA, USA). Serum-free testosterone levels were measured by radioimmunoassay. C-reactive protein (CRP) was determined using a BN II nephelometer (Siemens, Erlangen, Germany). Serum levels of 25-OHD, calcium, phosphorus, osteocalcin, deoxypyridinoline (DHP), fasting glucose, glycosylated hemoglobin $\left(\mathrm{HbA}_{1 \mathrm{c}}\right)$, and lipid profiles including $\mathrm{HDL}-\mathrm{C}$, low-density lipoprotein cholesterol (LDL-C), total cholesterol (TC), and TG were analyzed using an AU680 Chemistry System (Beckman Coulter) and appropriate reagents. Daily sun exposure and lifestyle, style of dress, age, body mass index (BMI), co-morbidities, smoking status, drug use and eating habits were recorded by the same doctor during face-to-face interviews with patients. "Covered clothing" was the description used when the head and arms were covered but the hands and face were not; "uncovered style of dress" was used when the head and arms were uncovered. BMI was calculated using the formula: BMI= weight $(\mathrm{kg}) /$ height $(\mathrm{m})^{2}$. Daily sun exposure times were divided into three categories as follows: A: less than 20 minutes of daily exposure, B: daily exposure of 20-30 minutes, and C: more than 30 minutes of daily exposure. All fresh blood samples were analyzed in our hospital's biochemistry laboratory.

\section{Laboratory analysis}

Serum levels of 25-OHD were measured using an enzyme-linked immunosorbent assay kit (Immunodiagnostic AG, Leverkusen, Germany) and are presented as $\mathrm{ng} / \mathrm{mL}$. Intra-assay and inter-assay coefficients of variation for serum $25-\mathrm{OHD}$ were 8.9 and $10.6 \%$, respectively. Serum $25-\mathrm{OHD}$ concentrations $<20 \mathrm{ng} / \mathrm{mL}(50 \mathrm{nmol} / \mathrm{L})$ were classed as vitamin D deficiency. Serum 25-OHD concentrations between 20 and $30 \mathrm{ng} / \mathrm{mL}$ were classed as vitamin D insufficiency and a threshold value of $\geq 30 \mathrm{ng} / \mathrm{mL}$ was classed as a sufficient vitamin D status. Serum osteocalcin was evaluated using immunometry, which only measures intact osteocalcin molecules (Immulite 1000 Osteocalcin, DPC, Los Angeles, CA, USA).

\section{Statistical analysis}

Statistical Package for the Social Sciences, version 22.0 (SPSS Inc., Chicago, IL, USA), was used for statistical analysis. The central limit theorem was used to determine sample size. Quantitative data are expressed as means and standard deviations, and quantitative data are expressed as numbers and percentages. KolmogorovSmirnov and Shapiro-Wilk tests were used to assess the normal distribution of univariate variables. Non-parametric methods were used to analyze non-normally distributed variables. Non-parametric variables between groups were compared by Mann-Whitney U-test. Independent samples t-test was used to compare unadjusted means between groups. Pearson's $X^{2}$ test was used for categorical variables. Spearman's correlation test was used to evaluate the relationship between vitamin D, osteocalcin and other parameters. Logistic regression analysis was also used to evaluate the risk factors that may cause metabolic syndrome in postmenopausal women. Statistical significance was set as $p<0.05$.

\section{Results}

\section{Demographic data}

The group characteristics are presented in $>$ Table 1 . Data were differentiated into the data of women with metabolic syndrome $(n=99)$ and the data of women without metabolic syndrome $(n=92)$. The prevalence of metabolic syndrome was calculated as $51.8 \%$. There was no significant difference in terms of age between women with and without metabolic syndrome. No significant differences were observed between groups with regard to cause of menopause, duration of menopause, number of miscarriages, duration of sun exposure, DHP, ALP, Ca and phosphorus levels (all $p>0.05$ ). However, a significant difference between groups was observed with regard to gravidity, parity and smoking status (all $p<0.05$ ).

\section{Anthropometric and laboratory measurements}

As expected, anthropometric measurements such as BMI, WC, HC and WHR were significantly higher in the metabolic syndrome group compared to the non-metabolic syndrome group (all 
- Table 1 Comparison of demographic data and clinical and laboratory characteristics of groups with and without metabolic syndrome.

\begin{tabular}{|c|c|c|c|}
\hline & Metabolic syndrome $(-)(n=92)$ & Metabolic syndrome $(+)(n=99)$ & $\mathbf{p}$ \\
\hline \multicolumn{4}{|l|}{ Demographic features } \\
\hline - Age (years) & $55.2 \pm 6.6$ & $56.8 \pm 6.0$ & 0.087 \\
\hline - Menopause duration (years) & $9.0 \pm 6.7$ & $8.6 \pm 5.8$ & 0.962 \\
\hline - Gravidity & $4.3 \pm 3.1$ & $5.3 \pm 3.1$ & 0.007 \\
\hline - Parity & $2.6 \pm 2.1$ & $3.0 \pm 1.5$ & 0.002 \\
\hline - Number of miscarriages & $0.4 \pm 0.8$ & $0.6 \pm 1.5$ & 0.675 \\
\hline Cause of menopause & & & 0.216 \\
\hline - Natural & $78(84.8)^{*}$ & $77(77.8)^{*}$ & \\
\hline - Surgical & $14(15.2)^{*}$ & $22(22.2)^{*}$ & \\
\hline History of osteoporosis & $5(5.4)^{*}$ & $5(5.1)^{*}$ & 0.905 \\
\hline Smoking & $36(39.1)^{*}$ & $18(18.2)^{*}$ & 0.002 \\
\hline Alcohol & $2(2.2)^{*}$ & $1(1.0)^{*}$ & 0.214 \\
\hline Sun exposure time (min/day) & $41.7 \pm 42.8$ & $34.6 \pm 46.0$ & 0.055 \\
\hline Systolic BP (mmHg) & $117.9 \pm 14.3$ & $124.7 \pm 15.8$ & 0.007 \\
\hline Diastolic BP $(\mathrm{mmHg})$ & $77.4 \pm 10.8$ & $81.1 \pm 10.2$ & 0.029 \\
\hline \multicolumn{4}{|l|}{ Anthropometric measurements } \\
\hline - BMI (kg/m²) & $28.0 \pm 4.9$ & $32.1 \pm 5.3$ & $<0.001$ \\
\hline - WC (cm) & $88.9 \pm 10.9$ & $99.2 \pm 9.2$ & $<0.001$ \\
\hline - $\mathrm{HC}(\mathrm{cm})$ & $109.7 \pm 12.1$ & $116.2 \pm 10.0$ & $<0.001$ \\
\hline - WHR & $0.81 \pm 0.05$ & $0.85 \pm 0.04$ & $<0.001$ \\
\hline \multicolumn{4}{|l|}{ Biochemical parameters } \\
\hline - hs-CRP (mg/dL) & $2.6 \pm 3.5$ & $4.4 \pm 4.4$ & $<0.001$ \\
\hline - 25-OHD (ng/mL) & $20.4 \pm 13.1$ & $16.1 \pm 11.2$ & 0.013 \\
\hline - Osteocalcin (ng/mL) & $5.5 \pm 3.0$ & $4.2 \pm 2.1$ & $<0.001$ \\
\hline - DOP (mg/dL) & $12.0 \pm 3.4$ & $12.1 \pm 3.4$ & 0.893 \\
\hline - ALP (U/L) & $84.4 \pm 22.9$ & $86.7 \pm 22.0$ & 0.367 \\
\hline - Ca (mg/dL) & $9.8 \pm 0.4$ & $9.8 \pm 0.4$ & 0.809 \\
\hline - Phosphorus (mg/dL) & $3.8 \pm 0.5$ & $3.8 \pm 0.5$ & 0.909 \\
\hline - HDL (mg/dL) & $55.3 \pm 11.1$ & $44.6 \pm 10.0$ & $<0.001$ \\
\hline - LDL (mg/dL) & $145.3 \pm 39.6$ & $143.9 \pm 40.3$ & 0.807 \\
\hline - TG (mg/dL) & $130.5 \pm 58.1$ & $193.8 \pm 89.8$ & $<0.001$ \\
\hline - FPG (mg/dL) & $92.6 \pm 10.8$ & $108.8 \pm 20.7$ & $<0.001$ \\
\hline - $\mathrm{HbA}_{1 \mathrm{c}}(\%)$ & $5.3 \pm 0.6$ & $5.9 \pm 0.9$ & $<0.001$ \\
\hline - HOMA-IR & $2.0 \pm 1.0$ & $4.2 \pm 3.4$ & $<0.001$ \\
\hline \multicolumn{4}{|l|}{ Hormonal parameters } \\
\hline - Insulin (mIU/L) & $8.7 \pm 3.8$ & $15.0 \pm 6.3$ & $<0.001$ \\
\hline - Estradiol (pg/mL) & $13.9 \pm 7.7$ & $20.7 \pm 12.9$ & 0.007 \\
\hline - FSH (U/L) & $73.1 \pm 29.3$ & $56.5 \pm 23.7$ & $<0.001$ \\
\hline - Free testosterone (pg/mL) & $1.5 \pm 0.6$ & $1.6 \pm 1.5$ & 0.258 \\
\hline - TSH (U/L) & $1.8 \pm 1.2$ & $1.8 \pm 1.1$ & 0.981 \\
\hline \multicolumn{4}{|l|}{ T-scores } \\
\hline - T-score (femur-neck) & $0.2 \pm 1.5$ & $0.6 \pm 1.2$ & 0.976 \\
\hline - T-score (total femur) & $0.3 \pm 1.4$ & $0.5 \pm 1.2$ & 0.091 \\
\hline - T-score (total L1-L4) & $-1.3 \pm 0.7$ & $-0.7 \pm 1.6$ & 0.743 \\
\hline
\end{tabular}

Abbreviations: BP: blood pressure, BMI: body mass index, WC: waist circumference, HC: hip circumference, WHR: waist-to-hip ratio, hs-CRP: highly sensitive Creactive protein, 25-OHD: 25-hydroxyvitamin D, DHP: deoxypyridinoline, ALP: alkaline phosphates, Ca: calcium, HDL: high-density lipoprotein, LDL: low-density lipoprotein, TG: triglyceride, FPG: fasting plasma glucose, HOMA-IR: homeostatic model assessment of insulin resistance, FSH: follicle-stimulating hormone, TSH: thyroid-stimulating hormone. Data are expressed as mean \pm standard deviation or ${ }^{*}$ number (percentage). A p value $<0.05$ is considered statistically significant. 
- Table 2 Distribution of serum 25-OHD levels according to the presence or absence of metabolic syndrome.

\begin{tabular}{|l|l|l|l|}
\hline Vitamin D levels $(\mathbf{n g} / \mathbf{m L})$ & Metabolic syndrome $(-)(\mathbf{n = 9 2})$ & Metabolic syndrome $(+)(\mathbf{n = 9 9 )}$ \\
\hline$<20$ & $53(57.6)$ & $70(70.7)$ \\
\hline $20 \leq$ and $<30$ & $22(23.9)$ & $18(18.2)$ \\
\hline$\geq 30$ & $17(18.5)$ & $11(11.1)$ \\
\hline Sun exposure time (min/day) & & \\
\hline$<20$ & $21(22.8)$ & $36(36.4)$ \\
\hline $20 \leq$ and $<30$ & $5(5.4)$ & $4(4)$ \\
\hline$\geq 30$ & $66(71.7)$ & $59(59.6)$ \\
\hline Data are expressed as numbers (percentages). & & \\
\hline
\end{tabular}

$\mathrm{p}<0.001)$. Serum 25-OHD levels were lower in the study group compared to controls $(20.4 \pm 13.1 \mathrm{ng} / \mathrm{mL}$ vs. $16.1 \pm 11.2 \mathrm{ng} / \mathrm{mL}$; $\mathrm{p}=0.013)$ and the difference was statistically significant. $>$ Table 2 shows the vitamin $D$ levels in both groups according to sun exposure times. The mean serum osteocalcin level in patients with metabolic syndrome was $4.2 \pm 2.1 \mathrm{ng} / \mathrm{mL}$, while the level in 92 patients without metabolic syndrome was $5.5 \pm 3.0 \mathrm{ng} / \mathrm{mL}$. Osteocalcin levels in women with metabolic syndrome were statistically significantly lower $(p<0.001)$. Serum CRP values were $4.4 \pm$ $4.4 \mathrm{mg} / \mathrm{dL}$ in patients with metabolic syndrome and $2.6 \pm$ $3.5 \mathrm{mg} / \mathrm{dL}$ in patients without metabolic syndrome, and the difference was statistically significant $(p<0.001)$. While HDL-C levels were significantly lower in the study group, TG levels were significantly higher in this group $(p<0.001)$. HOMA-IR, insulin and FPG levels were $4.2 \pm 3.4,15.0 \pm 6.3 \mathrm{mlU} / \mathrm{L}$, and $108.8 \pm 20.7 \mathrm{mg} / \mathrm{dL}$ in the metabolic syndrome group and $2.0 \pm 1.0,8.7 \pm 3.8 \mathrm{mIU} / \mathrm{L}$, and $92.6 \pm 10.8 \mathrm{mg} / \mathrm{dL}$ in the non-metabolic syndrome group, respectively. The results of the study group were higher compared to the control group and the difference was statistically significant $(p<0.001)$. The correlations between $25-\mathrm{OHD}$ and osteocalcin with other variables are shown in $>$ Table 3 . According to the correlation analysis, there was a significant positive correlation between 25-OHD and osteocalcin levels $(r=0.190$; $p=0.008)$. Serum 25-OHD levels were significantly positively correlated with daily sun exposure times $(r=0.181 ; p=0.012)$. An inverse correlation of 25-OHD with HDL and TG was observed for the total group $(r=0.011, p=0.006$, respectively). On the other hand, a significant negative correlation between osteocalcin and $\mathrm{HbA}_{1 \mathrm{c}}$ and HOMA-IR values was observed in this group $(p=0.001, p=0.048$, respectively.). Similarly, serum osteocalcin levels were negatively correlated with hs-CRP levels $(r=-204, p=0.003)$.

Logistic regression demonstrated that hs-CRP, vitamin $D$, and osteocalcin levels were risk factors for metabolic syndrome with odds ratios (95\% confidence interval) of 1.121 (1.012-1.242), 0.958 (0.930-0.986), and 0.798 (0.693-0.919), respectively ( Table 4).
- Table 3 Correlation analysis between 25-OHD, osteocalcin and other parameters.

\begin{tabular}{|c|c|c|c|c|}
\hline & \multicolumn{2}{|l|}{ 25-OHD } & \multicolumn{2}{|c|}{ Osteocalcin } \\
\hline & $r$ & p & $r$ & p \\
\hline 25-OHD & 1.000 & - & 0.190 & 0.008 \\
\hline Osteocalcin & 0.190 & 0.008 & 1.000 & - \\
\hline Age & 0.046 & 0.528 & -0.121 & 0.094 \\
\hline BMI & -0.122 & 0.093 & -0.130 & 0.074 \\
\hline WHR & 0.025 & 0.731 & -0.133 & 0.066 \\
\hline hs-CRP & -0.020 & 0.779 & -0.214 & 0.003 \\
\hline DOP & 0.245 & 0.001 & 0.340 & 0.000 \\
\hline ALP & -0.154 & 0.034 & 0.180 & 0.013 \\
\hline $\mathrm{Ca}$ & 0.122 & 0.093 & 0.107 & 0.140 \\
\hline Phosphorus & -0.148 & 0.041 & 0.134 & 0.065 \\
\hline $\mathrm{HDL}$ & -0.183 & 0.011 & 0.024 & 0.738 \\
\hline TG & -0.200 & 0.006 & 0.075 & 0.304 \\
\hline LDL & 0.047 & 0.522 & 0.135 & 0.063 \\
\hline PFG & -0.121 & 0.096 & -0.138 & 0.058 \\
\hline Insulin & -0.062 & 0.398 & -0.135 & 0.062 \\
\hline $\mathrm{HbA}_{1 \mathrm{c}}$ & -0.113 & 0.120 & -0.231 & 0.001 \\
\hline HOMA-IR & -0.104 & 0.153 & -0.143 & 0.048 \\
\hline Sun exposure & 0.181 & 0.012 & -0.008 & 0.908 \\
\hline $\begin{array}{l}\text { T-score } \\
\text { (femur-neck) }\end{array}$ & -0.096 & 0.608 & -0.317 & 0.082 \\
\hline $\begin{array}{l}\text { T-score } \\
\text { (total femur) }\end{array}$ & -0.149 & 0.423 & -0.133 & 0.477 \\
\hline $\begin{array}{l}\text { T-score } \\
\text { (total L1-L4) }\end{array}$ & 0.052 & 0.779 & 0.091 & 0.622 \\
\hline \multicolumn{5}{|c|}{$\begin{array}{l}\text { BMI: body mass index, WHR: waist-to-hip ratio, hs-CRP: highly sensitive } \\
\text { C-reactive protein, } 25-\mathrm{OHD}: 25 \text {-hydroxyvitamin D, DHP: deoxypyridino- } \\
\text { line, ALP: alkaline phosphates, Ca: calcium, HDL: high-density lipoprotein, } \\
\text { LDL: low-density lipoprotein, TG: triglyceride, FPG: fasting plasma glu- } \\
\text { cose, HOMA-IR: homeostatic model assessment of insulin resistance, } \\
\text { r: Spearman's correlation coefficient. A p value < } 0.05 \text { was considered } \\
\text { statistically significant. }\end{array}$} \\
\hline
\end{tabular}


- Table 4 Logistic regression for risk factors including bone turnover markers of metabolic syndrome.

\begin{tabular}{|c|c|c|c|c|}
\hline Variable & Wald & $\mathbf{p}$ & Odds ratio & $95 \% \mathrm{Cl}$ \\
\hline High sensitive CRP & 4.822 & 0.028 & 1.121 & $1.012-1.242$ \\
\hline 25-OHD & 8.561 & 0.003 & 0.958 & $0.930-0.986$ \\
\hline Osteocalcin & 9.828 & 0.002 & 0.798 & $0.693-0.919$ \\
\hline Deoxypyridinoline & 0.667 & 0.414 & 1.040 & $0.946-1.144$ \\
\hline Alkaline phosphatase & 0.034 & 0.854 & 1.001 & $0.986-1.017$ \\
\hline Calcium & 0.502 & 0.479 & 0.763 & $0.361-1.613$ \\
\hline Phosphorus & 0.075 & 0.784 & 0.924 & $0.525-1.627$ \\
\hline
\end{tabular}

25-OHD: 25-hydroxyvitamin D, Cl: confidence interval. A p value $<0.05$ is considered statistically significant.

\section{Discussion}

In this study, we found that osteocalcin, a bone turnover marker which is secreted from osteoblasts, was significantly decreased in patients diagnosed as having metabolic syndrome in the postmenopausal period with low vitamin D levels and normal bone mineral densitometry results [14].

As both vitamin D and osteocalcin levels are low in patients with metabolic syndrome, this suggests that these two markers may interact with each other. Osteocalcin appears to be the agent that is actually responsible. Osteocalcin is an important factor for both bone and energy metabolism and may be used as an additional marker with vitamin D [15].

According to a rat study, osteocalcin-deficient knockout mice showed glucose intolerance, increased fat mass, insulin resistance and low energy expenditure. The administration of recombinant osteocalcin to wild-type mice resulted in an increase in blood insulin levels and glucose tolerance, an improvement in insulin sensitivity and a decrease in the development of obesity. Although similar relationships have been reported for human studies, the number of studies on this has been low and most have been carried out in men and younger people [16-18].

Our patient group consisted of postmenopausal women with metabolic syndrome. The fact that osteocalcin levels in our study were significantly lower $(p<0.001)$ in individuals with metabolic syndrome supports the findings in the literature.

The postmenopausal period is a period in which vitamin $D$ inadequacy and deficiency are commom $[19,20]$. Vitamin D has receptors in many cells other than bone, making it a multifunctional micronutrient [21]. Numerous studies have described a relationship between vitamin $\mathrm{D}$ and metabolic syndrome; these studies have suggested that vitamin $D$ contributes to the prevention of atherosclerosis and foam cell formation and inhibits lipogenesis by stimulating lipolysis in adipocytes through the elevation of calcium, and that vitamin D deficiency is a risk factor for long-standing glucose intolerance [22]. However, a study by Kim et al. found no relationship between metabolic syndrome and vitamin D levels [23].

Osteocalcin is more bone specific compared to vitamin D. It is accepted that vitamin $D$ functions more like a hormone rather than having a primary effect on bone tissue. To investigate this re- lationship, a rat study was performed in vitamin D-deficient rats which showed that osteocalcin levels were deficient at tissue level and were similarly low in serum. When the rats were given vitamin $\mathrm{D}$, osteocalcin levels increased both in serum and in osteoblasts. Our own patient group had low levels of serum osteocalcin as well as low levels of vitamin D, which would appear to confirm that relationship. Based on the results of the rat study and our study, it appears that vitamin $\mathrm{D}$ has an effect on bone through osteocalcin [24].

In our study, we found that vitamin D levels were lower in patients with metabolic syndrome but the relationship between metabolic syndrome and osteocalcin turned out to be more significant.

The fact that vitamin D levels are lower in postmenopausal patients with normal bone mineral densities and the association with the inflammation marker CRP suggests that treatment with vitamin D could reduce micro-inflammation in patients with metabolic syndrome and improve metabolic parameters through the impact on osteocalcin $[25,26]$. As osteocalcin plays a role in insulin resistance and fat metabolism, this is not surprising.

We have not yet found another study in the literature that evaluates osteocalcin and vitamin D levels together in older, non-osteoporotic, postmenopausal women. The limitations of our study were that it was a cross-sectional study and samples were obtained during a period when sunlight was low. The comparison of vitamin $\mathrm{D}$ and osteocalcin levels in a postmenopausal population is one of the strengths of our study.

In conclusion, metabolic syndrome often occurs in the postmenopausal period, and vitamin D deficiency is common in nonosteoporotic postmenopausal women. Vitamin D deficiency may play an important role in the pathogenesis of metabolic syndrome. Given that vitamin D is significantly positively correlated with osteocalcin, the administration of vitamin D supplements to women with vitamin $\mathrm{D}$ deficiency may enhance osteocalcin levels. Additional vitamin $\mathrm{D}$ could improve insulin resistance and decrease subclinical systemic inflammation via osteocalcin-induced effects. In this group of patients, metabolic syndrome was better predicted by studying osteocalcin levels rather than vitamin D levels. Further research is necessary, but osteocalcin may be a good alternative to vitamin $\mathrm{D}$ in determining an association with metabolic syndrome. 


\section{Conflict of Interest}

The authors declare that they have no conflict of interest.

\section{References}

[1] Elsori DH, Hammoud MS. Vitamin D deficiency in mothers, neonates and children. J Steroid Biochem Mol Biol 2018; 175: 195-199

[2] Riedel J, Straub L, Wissing J et al. Vitamin D and Mammographic Findings. Geburtsh Frauenheilk 2016; 76: 570-578

[3] Rosen C]. Clinical practice. Vitamin D insufficiency. N Engl J Med 2011; 364: $248-254$

[4] Zhou P, Hu J, Xi P et al. Survey on the levels of 25-hydroxy vitamin D and bone metabolic markers and evaluation of their correlations with osteoporosis in perimenopausal woman in Xi'an region. PLoS One 2017; 12: e0180366

[5] Yasein N, Shroukh W, Hijjawi R. Serum vitamin D and the metabolic syndrome among osteoporotic postmenopausal female patients of a family practice clinic in Jordan. Adv Clin Exp Med 2015; 24: 245-250

[6] Chedraui P, Hidalgo L, Chavez D et al. Quality of life among postmenopausal Ecuadorian women participating in a metabolic syndrome screening program. Maturitas 2007; 56: 45-53

[7] Ding QF, Hayashi T, Zhang XJ et al. Risks of CHD identified by different criteria of metabolic syndrome and related changes of adipocytokines in elderly postmenopausal women. J Diabetes Complications 2007; 21: 315-319

[8] Buranasinsup S, Bunyaratavej N. The Intriguing Correlation between Undercarboxylated Osteocalcin and Vitamin D. J Med Assoc Thai 2015; 98 (Suppl. 8): S16-S20

[9] Demir B, Özkaya E, Öztürk N et al. Effectiveness of Different Treatment Modalities in Postmenopausal Women with Osteopenia and Osteoporosis. Gynecol Obstet Reprod Med 2009; 15: 153-156

[10] Oosterwerff MM, van Schoor NM, Lips P et al. Osteocalcin as a predictor of the metabolic syndrome in older persons: a population-based study. Clin Endocrinol (Oxf) 2013; 78: 242-247

[11] Köse G, Api M, Aka N. The Distribution of The Lumbal Bone Mineral Density Within Turkish Postmenopousal Female Population. Gynecol Obstet Reprod Med 2006; 12: 42-44

[12] World Medical Association. World Medical Association Declaration of Helsinki: ethical principles for medical research involving human subjects. JAMA 2013; 310: 2191-2194

[13] Alberti KG, Zimmet P, Shaw J. Metabolic syndrome-a new world-wide definition. A Consensus Statement from the International Diabetes Federation. Diabet Med 2006; 23: 469-480
[14] Kanbur NO, Derman O, Sen TA et al. Osteocalcin. A biochemical marker of bone turnover during puberty. Int J Adolesc Med Health 2002; 14: 235-244

[15] Hill HS, Grams J, Walton RG et al. Carboxylated and uncarboxylated forms of osteocalcin directly modulate the glucose transport system and inflammation in adipocytes. Horm Metab Res 2014; 46: 341-347

[16] Yeap BB, Chubb SA, Flicker L et al. Reduced serum total osteocalcin is associated with metabolic syndrome in older men via waist circumference, hyperglycemia, and triglyceride levels. Eur J Endocrinol 2010; 163: 265272

[17] Bao Y, Zhou M, Lu Z et al. Serum levels of osteocalcin are inversely associated with the metabolic syndrome and the severity of coronary artery disease in Chinese men. Clin Endocrinol (Oxf) 2011; 75: 196-201

[18] Tan A, Gao Y, Yang X et al. Low serum osteocalcin level is a potential marker for metabolic syndrome: results from a Chinese male population survey. Metabolism 2011; 60: 1186-1192

[19] Schmitt EB, Nahas-Neto J, Bueloni-Dias F et al. Vitamin D deficiency is associated with metabolic syndrome in postmenopausal women. Maturitas 2018; 107: 97-102

[20] Budak MŞ, Akgöl S, Önen Ş et al. Is Weekly Supplementation of Vitamin D Favorable for Treatment of Osteoporosis in Postmenopausal Women? Gynecol Obstet Reprod Med 2012; 18: 78-82

[21] Aghadavod E, Mollaei H, Nouri M et al. Evaluation of Relationship between Body Mass Index with Vitamin D Receptor Gene Expression and Vitamin D Levels of Follicular Fluid in Overweight Patients with Polycystic Ovary Syndrome. Int J Fertil Steril 2017; 11: 105-111

[22] Wang C. Role of vitamin d in cardiometabolic diseases. J Diabetes Res 2013; 2013: 243934

[23] Kim S, Kim J], Kim M] et al. Relationship between serum anti-Mullerian hormone with vitamin $\mathrm{D}$ and metabolic syndrome risk factors in late reproductive-age women. Gynecol Endocrinol 2017. doi:10.1080/ 09513590.2017 .1397113

[24] Lian J, Stewart C, Puchacz E et al. Structure of the rat osteocalcin gene and regulation of vitamin D-dependent expression. Proc Natl Acad Sci U S A 1989; 86: 1143-1147

[25] Schnatz PF, Vila-Wright S, jiang X et al. The association between plasma 25-hydroxyvitamin D3 concentrations, C-reactive protein levels, and coronary artery atherosclerosis in postmenopausal monkeys. Menopause 2012; 19: 1074-1080

[26] Ojeda Lopez R, Esquivias de Motta E, Carmona A et al. Correction of 25$\mathrm{OH}$-vitamin $\mathrm{D}$ deficiency improves control of secondary hyperparathyroidism and reduces the inflammation in stable haemodialysis patients. Nefrologia 2018; 38: 41-47 